\title{
PENGARUH MODEL PROBLEM BASED LEARNING TERHADAP KEMAMPUAN PEMECAHAN MASALAH PADA MATERI POKOK SUHU DAN KALOR DI KELAS X SEMESTER II SMA SWASTA AL-ULUM MEDAN T.P 2015/2016
}

\author{
Fitrah Yani Pasaribu dan Winsyahputra Ritonga \\ Jurusan Fisika FMIPA Universitas Negeri Medan \\ Jalan Willem Iskandar Pasar V Medan, Sumatera Utara \\ fitrah.yani9@gmail.com
}

\begin{abstract}
ABSTRAK
Penelitian ini bertujuan untuk mengetahui pengaruh model problem based learning terhadap kemampuan pemecahan masalah siswa kelas X semester II pada materi Suhu dan Kalor di SMA Swasta Al-ulum Medan T.P. 2015/2016. Jenis penelitian ini adalah quasi experiment. Populasi dalam penelitian adalah seluruh siswa kelas X SMA Swasta Al-ulum Medan T.P. 2015/2016. Pengambilan sampel dilakukan dengan cara cluster random sampling dengan mengambil 2 kelas sampel yaitu kelas $\mathrm{X}_{5}$ sebagai kelas eksperimen dan kelas $\mathrm{X}_{6}$ sebagai kelas kontrol yang masing-masing berjumlah 41 orang. Data yang digunakan dalam penelitian ini diperoleh dari tes kemampuan pemecahan masalah yakni tes uraian yang terdiri dari 10 item yang telah divalid kan oleh validator. Teknik analisis data yang digunakan adalah analisis varians satu jalur. Setelah diberikan perlakuan yang berbeda, kelas eksperimen dengan model $P B L$ dan kelas kontrol dengan pembelajaran konvensional, diperoleh hasil postes dengan hasil rata-rata kelas eksperimen 67,60 dan kelas kontrol 54,81. Hasil penelitian diperoleh dari perhitungan ANAVA 1x1 dengan menggunakan SPSS 16.0 diperoleh taraf signifikan 0,000 dimana nilai ini lebih kecil dari signifikan diperoleh sebesar 0,05 dengan $F_{\text {hitung }}>F_{\text {tabel }}$ yaitu $19.153>3,96$, Maka hipotesis nol $\left(\mathrm{H}_{\mathrm{o}}\right)$ ditolak hipotesis alternatif $\left(\mathrm{H}_{\mathrm{a}}\right)$ diterima dengan kata lain bahwa kemampuan pemecahan masalah menunjukan model $P B L$ di kelas eksperimen lebih baik dibadingkan model pembelajaran konvensional di kelas kontrol, berarti ada pengaruh yang signifikan dengan model $P B L$ terhadap kemampuan pemecahan masalah siswa kelas X semester II pada materi pokok Suhu dan Kalor di SMA Swasta Al-ulum Medan T.P. 2015/2016.
\end{abstract}

Kata kunci: Problem based learning, kemampuan pemecahan masalah, suhu dan kalor

\begin{abstract}
This study aimed to determine the effect of the model of problem based learning problem-solving skills of students of class $X$ in the second half of the material temperature and the Heat in Swasta School Al-ulum Medan T.P. 2015/2016. This research is a quasi experiment. The population in the study were all students of class $X$ SMA Swasta Al-ulum Medan T.P. 2015/2016. Sampling was done by cluster random sampling by taking a sample of grade 2 class as a class experiment X5 and X6 class as the control class. To obtain the data used in this study used the problem-solving ability
\end{abstract}


test description test consisting of 10 items that have been divalid the validator. Data analysis technique used is the analysis of variance of the lane. After being given a different treatment, the experimental class with a model of problem-based learning learningdan control class with a conventional, post-test results obtained with an average yield of 67.60 experimental class and control class 54.81. The results were obtained from the calculation 1x1 ANOVA using SPSS 16.0 was obtained a significant level of 0,000 which is smaller than the value obtained was 0.05 with significant Fhitung > Ftable is 19 153> 3.96, then Ho is rejected Ha accepted, in other words that the problem-solving abilities shows a model of problem based learning in the experimental class is better dibadingkan conventional learning models in the control class, meaning no significant effect with the model problem based learning to problemsolving ability of students of class $X$ the second semester in the subject matter of temperature and Heat in SMA Swasta Al-ulum Medan TP 2015/2016.

Keywords: Problem-based learning, problem solving ability, temperature and heat

\section{PENDAHULUAN}

Pendidikan merupakan dasar dalam memajukan suatu negara. Majunya suatu negara tercermin dari pendidikan yang maju dan mendapat perhatian secara serius. Undang-undang Nomor 20 Tahun 2003 tentang Sistem Pendidikan Nasional menyebutkan, bahwa pendidikan nasional berfungsi mengembangkan kemampuan dan membentuk watak serta peradaban bangsa yang bermartabat dalam rangka mencerdaskan kehidupan bangsa. Tujuan akhir dari pendidikan itu ialah mendidik anak agar berguna bagi dirinya sendiri serta berguna bagi masyarakat, bangsa dan negaranya (Ahmadi, dan Uhbiyati 2003). Penyebab rendahnya kualitas pendidikan di Indonesia salah satunya adalah lemahnya proses pembelajaran (Taufik, 2010).

Salah satu mata pelajaran yang memiliki nilai rendah adalah mata pelajaran fisika. Fisika sebagai salah satu mata pelajaran di sekolah merupakan mata pelajaran yang sangat berguna dan banyak memberi bantuan dalam berbagai aspek kehidupan. Fisika merupakan bagian dari Ilmu Pengetahuan Alam (IPA), yaitu suatu ilmu yang mempelajari gejala dan peristiwa atau fenomena alam serta berusaha untuk mengungkap rahasia dan hukum alam semesta. Permasalahan yang sering terdapat di dalam pembelajaran fisika adalah lemahnya proses pembelajaran yang terjadi di kelas. Proses pembelajaran masih didominasi oleh guru karena masih sering menggunakan pembelajaran konvensional. Siswa cenderung pasif dan kurang mampu menemukan konsep sendiri dari fakta yang ditemukannya serta tidak bisa mengaplikasikan konsep tersebut dalam kehidupan sehari-hari. Aktivitas belajar siswa dalam proses pembelajaran tergolong rendah kerena kurang adanya interaksi siswa dalam kegiatan belajar sendiri. Siswa kurang diperkenalkan dengan kerja di laboratorium fisika sehingga hal ini mengakibatkan hasil belajar siswa rendah.

Siswa akan terlatih menemukan sendiri berbagai konsep secara holistik, bermakna, otentik serta aplikatif untuk kepentingan pemecahan masalah. Hal ini pula yang menjadi salah satu tujuan pembelajaran fisika itu sendiri, yaitu mengembangkan kemampuan bernalar dalam berpikir analisis induktif dan deduktif dengan menggunakan konsep dan prinsip fisika untuk menjelaskan berbagai peristiwa alam dan menyelesaikan masalah baik secara kualitatif dan kuantitatif (Heriawan, dkk 2014)

Menurut Chi dalam sujarwanto dkk (2014) kemampuan pemecahan masalah merupakan aktivitas kognitif kompleks yang di dalamnya termasuk mendapatkan informasi dan mengorganisasikan dalam bentuk struktur pengetahuan. Dalam bidang 
fisika, pemecahan masalah fisika berkenaan dengan konsep fisika. Faktor yang mempengaruhi pemecahan masalah fisika adalah struktur pengetahuan yang dimiliki siswa untuk memecahkan masalah dan karakter permasalahan. Karakter permasalahan di antaranya ditunjukkan oleh format representasi soal yang disajikan. Perbedaan antara siswa yang memiliki kemampuan rendah (novice) dan tinggi (expert) dalam pemecahan masalah fisika adalah bagaimana siswa mengorganisasi dan menggunakan pengetahuan, serta menghubungkan satu konsep dengan konsep yang lain ketika memecahkan masalah. Siswa yang memiliki kemampuan tinggi dalam pemecahan masalah fisika cenderung menggunakan argumen kualitatif berdasarkan konsep fisika yang mendasari masalah (deep feature), mengevaluasi solusi, dan cenderung menggunakan alat bantu representasi. Hal sebaliknya, siswa yang memiliki kemampuan rendah dalam pemecahan masalah fisika cenderung mengenali masalah bedasarkan sajian masalah (surface feature), tidak melakukan evaluasi, dan cenderung menggunakan rumus dalam memecahkan masalah.

Informasi yang diperoleh berdasarkan hasil wawancara guru fisika dikelas X SMA Swasta Al-ulum Medan didapat bahwa minat siswa terhadap pelajaran fisika dikatakan masih dalam masuk kategori sedang, namun banyak siswa yang belum mampu mendapatkan hasil ulangan harian ataupun ujian melampaui batas KKM (kriteria ketuntasan minimum) yang telah ditetapkan, hal ini disebabkan karena siswa hanya menghapal rumus fisika saja, tidak memahami konsep fisikanya dan kemampuan dasar matematika yang masih lemah. Guru tersebut juga menambahkan bahwa berdasarkan hasil nilai dari ujian semester ganjil yang baru dilaksanakan, bahwa hanya $30 \%$ siswa yang mendapatkan nilai diatas KKM yaitu 60 . Selain melakukan wawancara dengan guru fisika, pembagian angket juga dilakukan kepada siswa dalam 1 kelas berjumlah 41 orang. Berdasarkan hasil angket diperoleh bahwa 37,5\% (16 siswa) menganggap bahwa pelajaran fisika itu biasa saja, 62,5\% (25 siswa) menganggap bahwa pelajaran fisika itu sulit, $23,7 \%$ siswa menyatakan bahwa kegiatan pembelajaran kadangkadang yang menggunakan alat peraga/demonstrasi yang berhubungan dengan materi fisika.

Salah satu upaya untuk mengatasi permasalahan tersebut di atas dimana proses pembelajaran ini berpusat kepada siswa, sehingga dapat melibatkan siswa secara aktif, dan memperhatikan kemampuan siswa. Salah satu alternatif model pembelajaran yang memungkinkan diterapkan yaitu dengan model $p b l$. Model $p b l$ ini siswa dituntut untuk melakukan pemecahan masalah-masalah yang disajikan dengan cara menggali informasi sebanyakbanyaknya, kemudian menganalisis dan mencari solusi dari permasalahan yang ada. Model pbl mengorientasikan siswa kepada masalah, multidisiplin, menuntut kerjasama dalam penelitian, dan menghasilkan karya. $P B L$ tidak dirancang untuk membantu guru menyampaikan informasi dengan jumlah besar kepada siswa. Tujuan $p b l$ adalah penguasaan isi belajar dari disiplin dan pengembangan keterampilan pemecahan masalah. Model ini juga berhubungan dengan belajar tentang hidup yang lebih luas (lifewide learning), keterampilan memaknai informasi, kolaboratif belajar tim, keterampilan berpikir reflektif dan evaluatif (Rusman, 2012)

Berdasarkan hasil penerapan model $P B L$ ini sebelumnya sudah diteliti oleh beberapa peneliti seperti Dewi, dkk (2014) dengan hasil penelitian nilai rata-rata kemampuan pemecahan masalah fisika siswa di kelas eksperimen dinyatakan meningkat dari kelas kontrol. Dari ketiga peneliti terdahulu dapat disimpulkan bahwa adanya pengaruh signifikan dengan model pbl pada kemampuan pemecahan masalah siswa.

\section{METODE PENELITIAN}

Penelitian ini dilaksanakan di kelas X, yang terdiri dari enam kelas. 
melibatkan dua kelas yang di beri perlakuan yang berbeda yang masing-masing kelas berjumlah 41 siswa. Kelas X-5 diberikan perlakuan model $p b l$ dan pada kelas X-6 diberi perlakuan model konvensional untuk mengetahui kemampuan pemecahan masalah siswa yang dilakukan dengan memberikan tes pada kedua kelas sebelum dan sesudah diberikan perlakuan. Penelitian ini termasuk jenis penelitian quasi experiment, yaitu penelitian yang dimaksudkan untuk mengetahui aktibat dari sesuatu yang dikenakan pada subjek yaitu siswa. Desain penelitian yang digunakan adalah two group pretest - posttest design. 
Gambar 1. Diagram Batang Data Pretes KPM Kelas Eksperimen dan Kelas Kontrol

Tes kemampuan pemecahan masalah siswa yang digunakan untuk mengukur penguasaan kognitif siswa pada materi suhu dan kalor. Tes disusun berdasarkan taksonomi Anderson dalam ranah kognitif yaitu: Mengingat $\left(\mathrm{C}_{1}\right)$, Memahami $\left(\mathrm{C}_{2}\right)$, Mengaplikasi $\left(\mathrm{C}_{3}\right)$, Menganalisis $\left(\mathrm{C}_{4}\right)$, Mengevaluasi $\left(\mathrm{C}_{5}\right)$, dan Mencipta $\left(\mathrm{C}_{6}\right)$. Instumen yang digunakan untuk mengumpulkan data kemampuan pemecahan masalah siswa adalah tes kemampuan pemecahan masalah siswa pada materi pokok suhu dan kalor yang terdiri dari 10 item dalam bentuk essay test. Alat pengumpul data sebelum digunakan terlebih dahulu akan divalidkan oleh validator. Pengujian hipotesis menggunakan teknik analisis varians satu jalur (desain faktorial 1x1) dengan taraf signifikan 5\% (Arikunto, 2012).

\section{HASIL DAN PEMBAHASAN Hasil Penelitian}

Data yang dideskripsikan pada penelitian ini meliputi data kemampuan pemecahan masalah siswa belajar fisika pada materi fluida statis, yang diberikan perlakuan berbeda yaitu 1) model problem based learning, 2) pembelajaran dengan menggunakan pembelajaran konvensional. Hasil data pretes siswa kelas eksperimen dan kelas kontrol dapat ditunjukkan pada gambar 1.

Gambar 1 menunjukkan bahwa nilai pretes pada kelas eksperimen mempunyai kemampuan awal pemecahan masalah dan perolehan nilai kedua kelas merata. Kelas eksperimen sebelum diberi perlakuan dengan model problem based learning terdapat nilai rata-rata kemampuan awal 42,6 dan standar deviasi. Sedangkan pada kelas kontrol sebelum diberi perlakuan dengan model konvensional terdapat nilai rata-rata kemampuan awal 41,01 dan standar deviasi 10,25. Setelah memperoleh data hasil pretes siswa dari kelas eksperimen dan kelas kontrol, maka dilakukan terlebih dahulu pengujian analisa data berupa uji normalitas dan uji homogenitas data pretes dan postes. Analisa data dilakukan yaitu pengujian normalitas data dengan uji liliefors dan uji homogenitas dengan uji kesamaan varians. Pengujian hipotesis pada data pretest dilakukan uji $\mathrm{t}$ dua pihak yaitu uji $\mathrm{t}$ dua pihak digunakan untuk mengetahui kesamaan kemampuan awal siswa pada kedua kelas sampel.

Gambar 2 Diagram Batang Data Postes KPM Kelas Eksperimen dan Kontrol

Ringkasan perhitungan uji hipotesis untuk kemampuan pretes kelas ekperimen dan kelas kontrol dapat dilihat pada gambar 2 yang menunjukkan nilai pretes $t_{\text {hitung }}<t_{\text {tabel }}$ yaitu $0,691<2,0066$ maka hipotesis nol $\left(\mathrm{H}_{\mathrm{o}}\right)$ diterima sehingga dapat disimpulkan bahwa kemampuan awal siswa pada kelas eksperimen sama dengan kemampuan awal siswa pada kelas kontrol.

Gambar 2 menunjukkan bahwa pada kelas eksperimen, nilai rata-rata tes akhir kemampuan pemecahan masalah setelah diberi perlakuan dapat dikatakan meningkat dengan model problem based learning 67,60 dan standar deviasi 12,01. Sedangkan dikelas kontrol nilai rata-rata meningkat setelah diberi perlakuan dengan model pembelajaran konvensional 54,81 dan standar deviasi 10,35. posttest siswa dari kelas eksperimen dan kelas kontrol, maka dilakukan terlebih dahulu pengujian analisa data berupa uji normalitas dan uji homogenitas data postes. Analisa data dilakukan yaitu pengujian normalitas data 
dengan uji liliefors dan uji homogenitas dengan uji kesamaan varians.

Pengujian hipotesis postest dilakukan dengan pengujian anava 1 jalur (1x1) yaitu pengujian hipotesis menggunakan teknik analisis varians satu jalur (desain faktorial 1x1) dengan taraf signifikan 5\%. Pengujian hipotesis penelitian dilakukan dengan menggunakan Analisis Varians (ANAVA) satu jalur. ANAVA satu jalur merupakan teknik analisis data penelitian dengan desain faktorial satu faktor. Uji ANAVA 1 jalur digunakan untuk mengetahui adanya perbedaan pengaruh yang signifikan dari suatu perlakuan yaitu model problem based learning terhadap kemampuan pemecahan masalah, jika $F_{\text {hitung }}>\mathrm{F}$ tabel pada taraf signifikan $\alpha$ dengan $\mathrm{db}$ yang sesuai, maka hipotesis nol $\left(\mathrm{H}_{\mathrm{o}}\right)$ ditolak, sedang sedang jika $F_{\text {hitung }} \leq \mathrm{F}_{\text {tabel}}$, maka hipotesis alternatif $\left(\mathrm{H}_{\mathrm{a}}\right)$ diterima. Adapun rumusan hipotesis statistik adalah sebagai berikut:

$\mathrm{H}_{\mathrm{a}}: \mu_{1}>\mu_{2}$ : Ada pengaruh penerapan model problem based learning terhadap kemampuan pemecahan masalah siswa pada materi pokok Suhu dan Kalor di kelas X SMA Swasta Al-ulum Medan T.P 2015/2016

Tabel 1 Uji Hipotesis Untuk Postest

\begin{tabular}{|cc|c|c|c|c|c|}
\hline \multicolumn{2}{|c|}{ Model } & $\begin{array}{c}\text { Sum of } \\
\text { Squares }\end{array}$ & df & Mean Square & F & Sig. \\
\hline \multirow{2}{*}{1} & Regression & 2716.878 & 1 & 2716.878 & 19.153 & $.000^{\mathrm{a}}$ \\
& Residual & 11347.902 & 80 & 141.849 & & \\
& Total & 14064.780 & 81 & & & \\
\hline
\end{tabular}

a. Predictors: (Constant), Model

b. Dependent Variable: Nilai

Hasil perhitungan ANAVA 1x1 diperoleh signifikan kelas sebesar 0,000 dimana nilai ini lebih kecil dari signifikan sebesar 0,05 dengan $F_{\text {hitung }}>F_{\text {tabel }}$ yaitu $19.153>3,96$, Maka hipotesis nol $\left(\mathrm{H}_{\mathrm{o}}\right)$ ditolak hipotesis alternatif $\left(\mathrm{H}_{\mathrm{a}}\right)$ diterima dengan kata lain bahwa kemampuan pemecahan masalah menunjukan model $p b l$ di kelas eksperimen lebih baik dari pada model pembelajaran konvensional di kelas kontrol, berarti ada pengaruh yang signifikan dengan model $P B L$ dapat mempengaruhi pemecahan masalah siswa kelas X semester II pada materi pokok Suhu dan Kalor di SMA Swasta Al-ulum Medan T.P. 2015/2016.

Hasil kemampuan pemecahan masalah dalam butir soal terdapat tahapan indikator kemampuan pemecahan masalah terbagi menjadi empat indikator yakni : 1) Memahami masalah, 2) perencanaan penyelesaian masalah, 3) penyelesaian masalah, 4) memeriksa kembali. Tahapan- tahapan ini perlu dideskripsikan dengan tujuan mengetahui berapa banyak siswa yang telah melakukan tahapan kemampuan pemecahan masalah pada kelas eksperimen dan kelas kontrol setelah diberikan perlakuan. Setiap indikator akan ditinjau berdasarkan butir soal.

1. Memahami Masalah

Presentase siswa yang melakukan tahapan memahami masalah pada kelas eksperimen yang diajarkan dengan model pbl yaitu $100 \%$. erbeda dengan perolehan presentase siswa pada kelas kontrol yang diajarkan dengan pembelajaran konvensional yaitu 90,2\%. Sehingga persentase pada kelas kontrol dengan model konvensional lebih rendah dibanding kelas eksperimen dengan model problem based learning.

2. Perencanaan penyelesaian masalah

Presentase siswa yang melakukan tahapan memahami masalah pada kelas eksperimen yang diajarkan dengan model 
problem based learningyaitu 80,4\%. Tingkat kemampuan pemecahan masalah pada indikator ini dikatagorikan "Tinggi". Namun berbeda dengan perolehan presentase siswa pada kelas kontrol yang diajarkan dengan pembelajaran konvensional yaitu $63,6 \%$ dikatagorikan "rendah".

Persentase pada kelas kontrol dengan model konvensional sangat rendah di bandingkan kelas eksperimen dengan model problem based learning.

\section{Penyelesaian Masalah}

Presentase siswa yang melakukan tahapan memahami masalah pada kelas eksperimen yang diajarkan dengan model problem based learningyaitu $72 \%$. Tingkat kemampuan pemecahan masalah pada indikator ini dikatagorikan "sedang". Namun berbeda dengan perolehan presentase siswa pada kelas kontrol yang diajarkan dengan pembelajaran konvensional yaitu $54,3 \%$ dikatagorikan "Sangat rendah". Sehingga persentase pada kelas kontrol dengan model konvensional sangat rendah dibanding kelas eksperimen dengan model problem based learning.

\section{Memeriksa Kembali}

Presentase siswa yang melakukan tahapan kemampuan memeriksa hasil pada kelas eksperimen yang diajarkan dengan model problem based learningyaitu $28,03 \%$. Tingkat kemampuan pemecahan masalah pada indikator ini dikatagorikan "sangat rendah". Sedangkan presentase siswa pada kelas kontrol yang diajarkan dengan pembelajaran konvensionalyaitu 8,7\% dikatagorikan "Sangat rendah". Hal ini disebabkan karena adanya ikatan erat dengan tahap sebelumnya.Siswa masih cenderung malas untuk memeriksa pengerjaan dari langkah-langkah pengerjaan sebelumnya dan beberapa siswa berpendapat bahwa tidak perlu dilakukan pemeriksaan kembali terhadap pelaksanaan penyelesaian masalah.

Berdasarkan tahapan indikator kemampuan pemecahan masalah terdapat bahwa hasil nilai rata-rata di postest lebih tinggi dari pada kelas kontrol.. Hal ini dapat dilihat dari hasil posttest dari kelas eksperimen lebih baik daripada hasil posttes kelas kontrol yang menunjukkan bahwa siswa yang diajarkan dengan model $p b l$ terhadap kemampuan pemecahan masalah siswa di kelas eksperimen dalam kategori "sedang" dengan rata-rata postest 67,60. Sedangkan dikelas kontrol siswa diajarkan melalui pembelajaran konvensional terhadap tingkat kemampuan pemecahan masalah siswa di kelas kontrol dalam kategori "sangat rendah" dengan nilai ratarata postest 54,81. Peneliti tidak menemukan nilai KKM siswa pada hasil postest. Akan tetapi siswa mendapatkan peningkatan terhadap kemampuan pemecahan masalah. Hal ini sesuai dengan hasil penelitian Dewi dkk (2014) yang menyatakan bahwa terdapat rata-rata perbedaan kemampuan pemecahan masalah matematis siswa menggunakan problem based learning lebih baik daripada rata-rata perbedaan kemampuan pemecahan masalah matematis siswa dengan pembelajaran konvensional. Dengan demikian terdapat perbedaan kemampuan pemecahan masalah yang signifikan antara siswa yang diajar dengan model problem based learning dengan pembelajaran konvensional. Hal senada juga diungkapkan oleh Abd El-hay, dan Abdullah (2015) dalam hasil penelitiannya yang menyatakan bahwa adanya peningkatan statistik yang signifikan dalam penilaian kemampuan pemecahan masalah setelah dilakukan penerapan strategi $p b l$ terhadap siswa dengan sebelum dilakukan perlakuan. Sikap siswa dan evaluasi diri berdasarkan pengalaman saat dilaksanakan strategi pembelajaran berbasis masalah adalah positif. Dan juga partisipasi, komunikasi dan kemampuan membuat keputusan menyebabkan terjadinya peningkatan kemampuan pemecahan masalah setelah diterapkan strategi model $p b l$ tersebut.

Menurut Arends (2008) model problem based learning ini menyusun pengetahuan mereka sendiri, mengembangkan inkuiri dan kemampuan 
berpikir tingkat tinggi, mengembangkan kemandirian dan percaya diri. Langkahlangkah pembelajaran pada model $p b l$ ini mendorong siswa untuk lebih aktif di dalam kelas. Tahapan-tahapan model pbl pada tahap pertama yaitu orientasi siswa pada masalah peneliti memotivasi siswa dengan memberikan tujuan pembelajaran yang akan dicapai oleh siswa dan pada tahap ini peneliti memberikan masalah kepada siswa dengan pertanyaan sederhana yang berbeda didalam kehidupan sehari-hari siswa. Pada tahap kedua yaitu mengorganisasikan siswa untuk belajar, peneliti memberikan materi pelajaran dengan menggunakan model problem based learning terhadap kemampuan pemecahan masalahpeneliti kemudian membentuk kelompok-kelompok belajar dan melakukan percobaan (eksperimen). Pada tahap ini siswa terbagi dalam 8 kelompok mendefinisikan masalah yang diberikan pada LKS. Siswa menghubungkan masalah yang disajikan dengan konsep yang ada pada literatur. Setiap siswa dalam kelompok saling bertukar pikiran dengan memberikan tanggapan tentang permasalahan tersebut. Hal ini membuat siswa semakin terampil berkomunikasi dengan sesama anggota kelompok dalam memberikan tanggapan. Hasil dari buah pemikiran yang telah disepakati bersama itu yang menjadi hipotesis permasalahan dari kelompok siswa. Pada tahap ketiga yaitu penyelidikan individual atau kelompok, peneliti membimbing setiap siswa untuk mengumpulkan informasi untuk memecahkan masalah, dan melakukan percobaan sekali lagi.

Kendala pada tahap ini yaitu saat pelaksanaan praktikum siswa terlalu ribut, karena siswa kurang mampu dalam melakukan praktikum sesuai prosedur. Pada tahap keempat yaitu mengembangkan dan mempresentasikan artefak dan exhibit, peneliti membantu setiap kelompok menyelesaikan dan menjawab semua permasalahan yang ada, serta mempresentasikan hasil diskusi kelompok yang sudah disiapkan, kemudian kelompok yang lain diberikan kesempatan memberikan pendapat atau masukan.

Kendala dalam tahap ini yaitu pada saat menyajikan hasil diskusi, sebagian siswa kurang antusias untuk presentasi melainkan memilih diam dan menunggu pendapat temannya, hal ini dikarenakan siswa kurang memahami kegiatan pembelajaran yang berlangsung. Pada tahap kelima yaitu menganalisis dan mengevaluasi proses mengatasi masalah, peneliti membantu siswa dalam mengkaji ulang pemecahan masalah sesuai dengan tujuan pembelajaran dan memberikan penguatan pada pemecahan masalah tersebut dan pada tahap ini peneliti membuat tes evaluasi untuk mengetahui pemahaman siswa. Pada tahap ini kendala yang dihadapi peneliti yaitu pada saat peneliti membantu siswa untuk memecahkan masalah. Akan tetapi, kebanyakan siswa tidak memperhatikan, hal ini dikarenakan siswa belum memahami konsep yang diajarkan peneliti kepada siswa.

\section{KESIMPULAN DAN SARAN Kesimpulan}

Berdasarkan hasil analisis data penelitian dan pembahasan, dapat disimpulkan bahwa, hasil penelitian diperoleh dari perhitungan ANAVA 1x1 dengan menggunakan SPSS 16.0 diperoleh taraf signifikan 0,000 dimana nilai ini lebih kecil dari signifikan diperoleh sebesar 0,05 dengan $F_{\text {hitung }}>F_{\text {tabel }}$ yaitu $19.153>3,96$, Maka hipotesis nol $\left(\mathrm{H}_{\mathrm{o}}\right)$ ditolak hipotesis alternatif $\left(\mathrm{H}_{\mathrm{a}}\right.$ diterima dengan kata lain bahwa kemampuan pemecahan masalah menunjukan model $P B L$ di kelas eksperimen lebih baik dibadingkan model pembelajaran konvensional di kelas kontrol, berarti ada pengaruh yang signifikan dengan model $P B L$ terhadap kemampuan pemecahan masalah siswa kelas $\mathrm{X}$ semester II pada materi pokok Suhu dan Kalor di SMA Swasta Al-ulum Medan T.P. 2015/2016.

\section{Saran}

Berdasarkan hasil penelitian dan kesimpulan di atas, maka sebagai tindak 
lanjut dari penelitian ini disarankan beberapa hal sebagai berikut :

1. Kepada guru ataupun calon guru yang berencana menggunakan model pembelajaran berbasis masalah supaya lebih banyak lagi mempersiapkan masalah - masalah dalam kehidupan sehari -hari dan dalam pengunaan media lainnya yang menarik dan terkait pada materi pembelajaran sehingga siswa lebih tertarik mengikuti pelajaran.

2. Hendaknya melakukan simulasi sebelum mencobakan model ini terhadap siswa agar siswa lebih memahami dan terlatih dengan cara kerja model pembelajaran ini ketika melakukan penelitian, sehingga model pembelajaran berbasis masalah ini dapat diselesaikan tepat waktu.

3. Bagi peneliti selanjutnya yang ingin melakukan penelitian dengan menggunakan model pembelajaran berbasis masalah, sebaiknya menguasai terlebih dahulu setiap sintaks yang terdapat dalam model, supaya kegiatan pembelajaran dapat berlangsung dengan baik

4. Bagi peneliti selanjutnya hendaknya harus lebih tegas lagi dalam mengontrol kelas saat melaksanakan diskusi kelompok sehingga kelas menjadi lebih kondusif.

\section{DAFTAR PUSTAKA}

Abd El-Hay S., dan Abdullah S. (2015), Effect of Problem-Based Learning Strategy on Development of Problem Solving Skills among Undergraduate Nursing Students,
Journal of Nursing and Health Science (IOSR-JNHS), 4(3) : 1-13.

Ahmadi, A dan Uhbiyati, N, (2003), Ilmu Pendidikan, Jakarta, Rineka Cipta.

Arends,R,I., (2008), Learning to teach,Salemba Humanika, Yogyakarta.

Arikunto, S, (2012), Dasar-Dasar Evaluasi Pendidikan Edisi 2, Jakarta, Bumi Aksara

Dewi, P.,U.,S., Sadia, I.,W., Suma, K., (2014), Pengaruh Model Problem Based Learning Terhadap Kemampuan Pemecahan Masalah Fisika Melalui Pengendalian Bakat Numerik Siswa SMP, Journal Program Pasca Sarjana Pendidikan Fisika.4(3) : 2-11.

Heriawan.,Kamaluddin.,Wahyono,U.

(2014). Pengaruh Model Pembelajaran Creative Problem Solving Terhadap kemampuan Memecahkan Masalah Fisika Pada Siswa Kelas XI SMA Negeri 4 Palu, Journal Perndidikan Fisika Tadulako.1(2) : $3-4$ ISSN 2338 3240.

Rusman, (2012)

Model-Model Pembelajaran, Rajawali Press, Jakarta.

Taufik, Mohammad.,S.,N., (2010), Desain Model Pembelajaran untuk Meningkatkan Kemampuan Pemecahan Masalah dalam pembelajaran IPA (Fisika) Sekolah Menengah Pertama di Kota Bandung, Journal pendidikan Fisika (IPA) Universitas Padjajaran, 13(2): E31-E44, ISSN : 1410 - 9662 

